\title{
Universal screening for drug use in urban primary care
}

\author{
Richard Saitz", Daniel Alford, Julie Witas, Donald Allensworth-Davies, Tibor Palfai, Debbie Cheng, Judith Bernstein, \\ Jeffrey Samet
}

From International Network on Brief Interventions for Alcohol Problems (INEBRIA) Meeting 2011

Boston, MA, USA. 21-23 September 2011

We describe universal screening in a large urban hospitalbased primary care practice. Trained staff aimed to screen all adult patients presenting for primary care visits between July 2010 and February 2011. Screening included three items about past three-month drug use: frequency of heavy drinking ( $>3$ standard drinks in a day for women and $>4$ for men); any use of prescription sedatives, opioids, or amphetamines without a prescription or in greater amounts than prescribed; and any use of illicit drugs. A convenience sample of those who screened positive for drug use was evaluated for eligibility to be in a study of brief counseling efficacy; enrollment resulted in further research assessment. During six months, 15,818 patients arrived for primary care appointments. Of these, 5549 (35\%) were screened, 539 (10\%) of whom reported heavy drinking (5.9\% of those screened) or drug use $(6.2 \%$ of those screened). Of the $539,41 \%$ reported drug use only, $38 \%$ heavy drinking only, and $21 \%$ reported both. Of patients meeting eligibility criteria for the brief counseling study for drug use (current drug use, not pregnant, able to provide two contacts for follow-up, willing to return for research assessments, spoke English), 14\% had lower risk scores (2 or 3) on the Alcohol, Smoking, and Substance Involvement Screening Test (ASSIST). Of those with scores of 4 or more (moderate risk), marijuana was the drug of most concern for $61 \%$, cocaine for $19 \%$, and opioids for $18 \%$. Twenty-one percent reported prescription drug misuse, 31\% used more than one drug, 20\% had high-risk ASSIST scores (27+), and 48\% met criteria for drug dependence. In-person universal screening in busy urban primary care settings reaches some but misses many. Drug use prevalence was $6.2 \%$, most of which was marijuana, and many of those screened had drug dependence. Most drug use

Boston University School of Medicine and Boston Medical Center, Boston, MA, USA

C Biomed Central

(c) 2012 Saitz et al; licensee BioMed Central Ltd. This is an Open Access article distributed under the terms of the Creative Commons Attribution License (http://creativecommons.org/licenses/by/2.0), which permits unrestricted use, distribution, and reproduction in any medium, provided the original work is properly cited. would have been missed if drug screening had been done only for those who screened positive for heavy drinking.

Published: 9 October 2012

doi:10.1186/1940-0640-7-S1-A14

Cite this article as: Saitz et al:: Universal screening for drug use in urban primary care. Addiction Science \& Clinical Practice 2012 7(Suppl 1):A14.

Submit your next manuscript to BioMed Central and take full advantage of:

- Convenient online submission

- Thorough peer review

- No space constraints or color figure charges

- Immediate publication on acceptance

- Inclusion in PubMed, CAS, Scopus and Google Scholar

- Research which is freely available for redistribution Submit your manuscript at
www.biomedcentral.com/submit C BioMed Central 